\title{
Syntactic and Semantic Analysis of Urdu Modal Verbs using XLE Parser
}

\author{
Qaiser Abbas \\ Department of Computer \\ Science \& IT \\ University of Sargodha, 40100, \\ Sargodha, Pakistan
}

\author{
Tehseen Zia \\ Department of Computer \\ Science \& IT \\ University of Sargodha, 40100, \\ Sargodha, Pakistan
}

\author{
Ahsan Nabi Khan \\ Data Scientist @Teradata \\ Teradata Alumni of UET and \\ NUCES, Lahore, Pakistan
}

\begin{abstract}
In this extended work, a syntactic and semantic analysis of Urdu Modal verbs is presented using lexical functional grammar encoded in an environment of the XLE parser. This grammar is developed to understand the syntactic and semantic structure of Urdu modal verbs taken from the sentences of a corpus. Based on this analysis, Urdu modal verbs are finally classified. The corpus is analyzed and sentences including modal verbs like كر يانا (kar pAnA) 'can

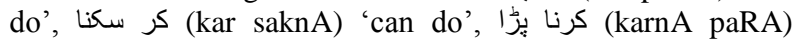
'must/obliged to do', etc., are extracted from the corpus. Rules are studied, analyzed and encoded for these particular sentences in the form of lexical functional grammar which provides us finally the syntactic and semantic structure of different classifications.
\end{abstract}

\section{General Terms}

Computational Linguistics, Natural Language Processing, Language Engineering, Linguistics

\section{Keywords}

Lexical Functional Grammar; Urdu Modal Verbs; XLE Parser; Classification; C-Structure; F-Structure;

\section{INTRODUCTION}

The types of modal verbs include andative and venitive, anticausative, captive, catenative, ditransitive, frequentative, germanic, intensive, intransitive, light, momentane, predictive, transitive, copula, etc. A detail discussion on these types can be seen in $[9,16]$ or in the initial version of this work [15].

Modal verbs provide additional information about the main verb (predicate) of the sentence. It has a scale ranging from possibility (can) to necessity (must) which is further divided into two functional divisions. One is freedom to act which includes ability, permission and duty. Other includes likelihood or certainty e.g. must is used in sentences where absolute obligation, order, requirement and necessity, etc., are demanded, can/could represents physical or mental ability, may/might represents permission, option or choice. Similarly, will demonstrates intention in $1^{\text {st }}$ person, volition in $2^{\text {nd }}$ and $3^{\text {rd }}$ person, shall/should is objective in $1^{\text {st }}$ person though not moral obligation. In $2^{\text {nd }}$ and $3^{\text {rd }}$ person, shall imply an obligation imposed by the speaker. However, shall/will misleads us in future tense auxiliary verbs where shall is used for $1^{\text {st }}$ person and will is used for $2^{\text {nd }}$ and $3^{\text {rd }}$ person or shall and will are interchangeable in modern English. Modal auxiliary verbs are classified in two distinct interpretations. One is epistemic claiming how certain the factual status of the embedded proposition is while the other is deontic included notions of permission and obligation $[3,7]$.
Modal verbs have been categorized into many different forms. Their simple forms are self-explanatory and their discussion can be seen in [4]. For example, I could swim at the beach (Modal Simple), I could be swimming at the beach right now (Modal Continuous), I could have swum at the beach yesterday (Modal Perfect). Similarly, had better can be used to represents recommendation, desperate, or warn in many cases. For example, You had better take your luggage with you is the recommendation, That girl had better get here soon! is the case of desperate hope, while You had better watch the way you talk to me in the future! is a warning to some person. Similarly, have to is used to express certainty, necessity and obligation while have got to is used to express necessity and obligation. Ought to, is used when advice or recommendation is required e.g. you ought to stop smoking (Recommendation) etc. It also represents assumption or expectation as strong probability, Ought not without to is also used to advise something. Many other modal verbs with examples are discussed in [4]. A similar study was performed by Abbas et. al, but on Urdu copula verbs with a little different approach which can be seen in [10].

In Urdu, the verb has four divisions in major e.g. root, imperfective participle, perfective participle and infinitive. Detailed divisions of verbs can be seen in [11, 12,]. Auxiliaries and suffixes transfer it into a complex system of verb tense and aspect described in [13]. The information of verbs and auxiliaries can also be encoded at part of speech (POS) level discussed in [14]. The verb root can be used with modal verbs e.g. سكنا (saknA) 'to be able' to show ability and ج (cuknA) 'to be finished' to show completion. The preliminary work on Urdu modals was discussed in [15]. As سكنا represents the ability to perform an action or possibility of an event occurring. It is intransitive and determines the grammar of the sentence. Its usage is always considered as modal verb like in (I). It is shown that in imperfective tenses, سكتا (saktA) agrees with the subject 'My child' and infinitive form $\mathrm{L}(\mathrm{nA})$ is not been used even the root from of the verb belongs to a transitive verb.

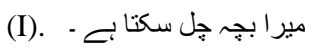

Transliteration: mErA bacah cal saktA hE

Translation: 'My child can walk'

The tense of سكنا (saknA) can also determine the form of negatives as in (II).

(II). وحيد بيمار بـه كل كى دعوت ميل نبيس آسكح كا

vah2Id bEmAr hE kal kI davit mEN nahI A sakE gA

'Wahid is sick, he won't be able to come at tomorrow's Party'

Similarly, the word (pAnA) showing the possibility of an action dependent on other circumstances is used mostly in 
negative aspect. The verb phrase has the structure as VERB ROOT + inflected form of پان while the verb phrase structure of سكنا is VERB ROOT + inflected form of سكنا Lكe example of phrase structure with يان is given in (III).

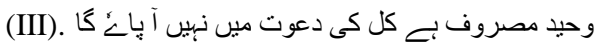

vah2Id mas2ruf hE kal kI davat mEN nahI A pAyE gA

'Wahid is busy; he cannot manage to come at tomorrow's party'.

In this sentence يان is used as modal and is intransitive. It agrees with the subject as advocated in [8]. In contrast, it can also be used as a non-modal verb with transitive valency when used as a sentence predicate like in (IV).

(IV). انجم نه امتحان ميب اجهم نمبر بانـ

anjum $\mathrm{nE}$ imtEh2An mEN acHE nambar pAyE

'Anjum got good marks in the examination'.

The modal verb جִ (cuknA) shows the completion of an action or event prior to a second action or event mostly used in perfective tenses. Its phrase structure is given as VERB ROOT + inflected form of جكنا. It is confusing because it remains intransitive even in the case of perfect tense and (na) cannot be used when the verb root form belongs to transitive verb like in $(\mathrm{V})$.

(V). بم كازٔى بيج جكه تهم جب ملى صاحب نه دريافت كيا

ham gARI bEc cukE tHE jab malik s2Ahib nE daryaft kiyA

'We had already sold the car when Malik Sahib inquired about it'.

Modal infinitives are divided into personal and impersonal constructions. Its phrase structure is NOMINATIVE INFINITIVE + an inflected form of جابنا (cAhnA) 'to want (to)'. The subject is nominative, however if an infinitive form has an object, then it can also agree optionally with it like adjectives.

The impersonal infinitive has the structure NOMINATIVE INFINITIVE + IMPERSONAL VERB and the necessity ranging from advisability to lack of choice. Verb agrees with the object if present unless the object is followed by the postposition. The infinitive also agrees with it, but this agreement is weakened in longer sentences and it remains masculine singular. In place of 'should to' or 'ought to' of English modal verbs, the Urdu has NOMINATIVE INFINITIVE + جائيّ (cAhiyE) represents advisability or wish or necessity. It agrees with the object of infinitive in number, unless the past auxiliary is added to the phrase as in (VI).

\section{(VI). مجهم سير كرنى جائيح}

mujhE sEr karnI cAhiyE

'I should go for a walk'

Where I-OBL-DAT (subject) should do-INF-f ( INF-m.sg) wished (sg) and a sentence in (VII).

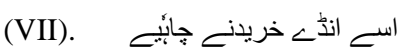

usE andE XarIdnE cahiyE

'He should buy eggs'
Where he-obl.-DAT egg-pl. buy-INF-m.pl ( INF-m.sg) wished-pl. In (VI) and (VII), the modal verb 'have to' has a structure in Urdu as NOMINATIVE INFINITIVE + AUXILIARY shows necessity. Moreover, if the subject is inanimate then the dative case marking is not required as in (VIII).

(VIII). مجه وه كتاب بُرْنى بـ

mujHE voh kitAb paRHnI hE

'I have to read that book'

Where I-OBL.-DAT that book read-INF-F.( INF-M-SG.) AUX-3SG. Some other auxiliaries are also used like بو كَ (hO gI) and تهى (tHI) and much more like in (IX).

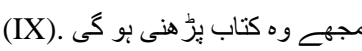

mujHE voh kitAb paRHnI hO gI

'I will have to read that book'

Where I -OBL.DAT that book read-INF-F.SG ( INF-M.SG) AUX-3SG. FUT-F.SG. There are issues in modal verbs like 'telic aspect' and 'marker of sources', which are clarified in

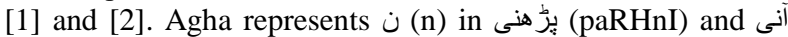
(AnI) as an aspectual marker called as TELIC aspect [5]. He argues that (nA) in هنا بـ (paRHnA hE) is homophonous with the infinitive marker $L$ but has a different morphological composition as in the reproduced version of (IX) as I -OBL.DAT that book read-TEL-F. AUX-3SG. He also argues that split in case inflection (dative with [+animate] and nominative with [-animate] is aspectually driven and thus comparable to the split ergative of the perfective aspect. The مصييت (mus2Ibat) being inanimate takes the nominative as in (X).

(X). مصييت آنى به

mus2Ibat AnI hE

'Misfortune is bound to strike'

In misfortune come-TEL-F AUX-3SG, [1] does not call it the 'telic participle' but the agreement of infinitive with its object is a pattern usually associated with participles and not with infinitives, which are basically verbal nouns. Similarly, [2] gives NOMINATIVE INFINITIVE + AUXILIARY with ergative case marking by $\dot{\sim}(\mathrm{nE})$ of the subject in Urdu of Pakistan. He declared it as a marker of source in a generalized sense. In the sentence in (XI).

(XI). آج مين نـ ضرور جانا بـ

Aj mEN nE z2arUr jAnA hE

'Today I am definitely going [+conscious choice]'

Where today I-ERG certainly go-INF AUX-3SG Volition is involved. By contrast, dative subject is usually unmarked for SOURCE, so the issue of volition does not arise in (XII).

(XII). مجهم ضرور جانا به

mujHE z2arUr jAnA hE

'Today I definitely have to go [-conscious choice]'

Where today I-OBL.-DAT certainly go-INF AUX-3SG is the glossing of (XII). This gives an idea of the form as an unexplored dimension of the modal system at least in Pakistani Urdu. The English word 'must' has structure in Urdu as NOMINATIVE INFINITIVE + inflected form of (paRnA) 'to fall, befall'. It represents external compulsion or lack of choice as in (XIII). 


\section{(XIII). مجه يـ كزّوى دوا كهانى بـ}

mujHE yE kaRvI davA kHanI hE

'I must take this bitter medicine'

Where I-OBL.-DAT this bitter-F medicine eat-INF-F ( INFM.SG) befall-PFV.-F AUX-3SG.

After presenting the introduction to categories of Urdu modal verbs, the method performed to analyze these proposed categories is discussed in Section 2 along with the grammar. The variations found in this study of modal verbs are discussion in Section 3. Finally, the discussion and conclusion in presented in Sections 4 and 5 respectively.

\section{METHODOLOGY}

Methodology involves three steps. At first, we searched through the corpus keenly and identified those sentences which contained modal verbs. POS tagging was done using a tagger developed by Hassan [6]. Underlying structure was observed then by using the tags assigned to the verb phrases. Secondly, we determined the syntactic and semantic structure governing the varieties of modals and developed a LFG (lexical functional grammar) framework. Thirdly, we implemented the LFG using XLE Parser and analyzed the results.

A corpus of more than 114,000 words was used to find the modal verbs which contained text mostly from newspapers and 210 sentences containing modal verbs were tagged which were identified in the first step. The tag set and the technology used has been mentioned earlier. Variations in the modal verbs were recorded and shown in results. In order to streamline the steps solely for modal verb analysis, LFG vocabulary is limited to the words dependent on modals only. The rest of the words were substituted for the ease of comparison, thus parsing and testing was rendered easily. Simple past tense for implementing the LFG for most of the modal verbs was taken. Since our analysis was not on the tense, so we took these variations as constant in our analysis. We converted the verbs that differ in tense to the above form. The two exceptions are in the modal categories of 'advised' and 'binding' as can be seen in the results. They are always used in infinitive sense.

We chose different values of gender and case in order to observe the agreement in constituent structures. The rules discovered are mentioned in results. Two LFG files (grammar rules and lexicon) are created with a common lexicon. Grammar rules recognize Nominative Case sentences and the lexicon recognizes Ergative and Dative cases. These files of grammar rules and lexicon are given in Figure 1. Where the POS are m: modal, v: main verb, n: noun, $\mathrm{cm}$ : case marker

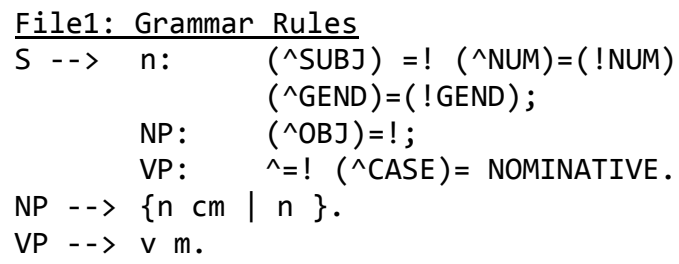

\section{File 2: Lexicon}

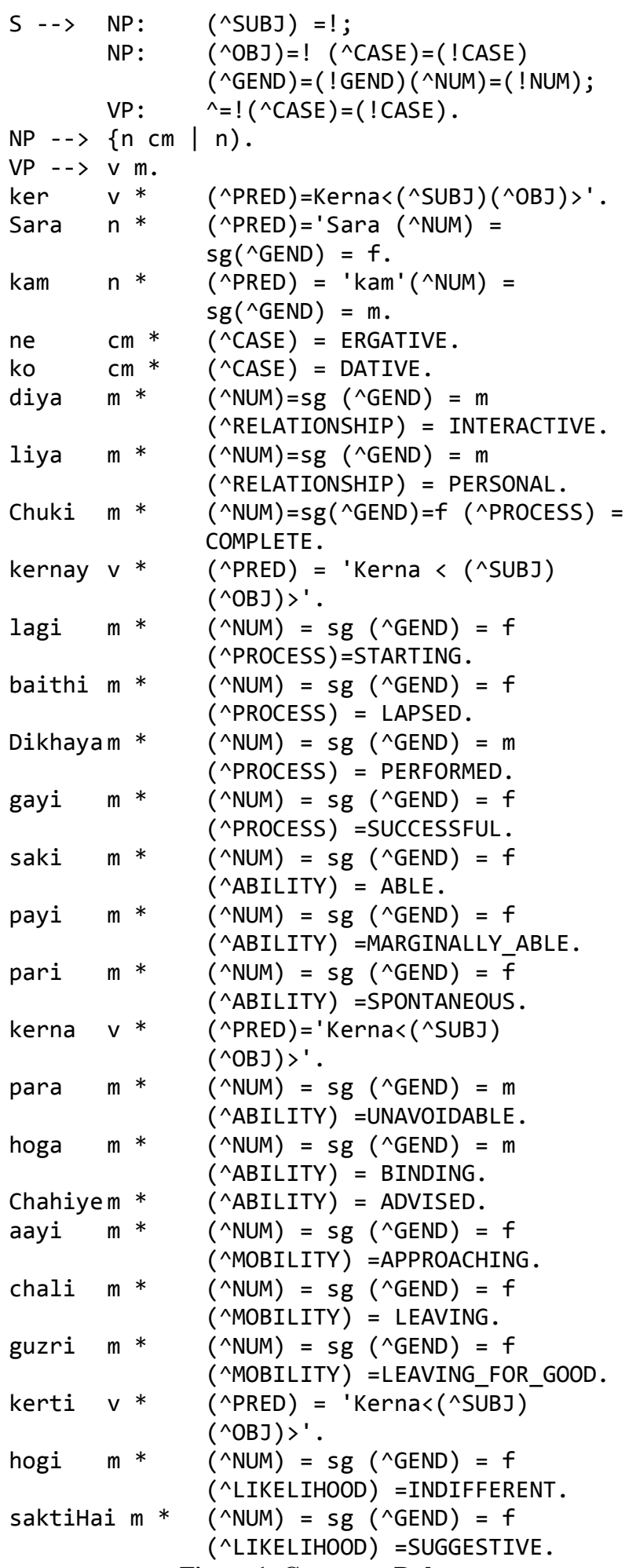

Figure 1: Grammar Rules

\section{RESULTS}

After analyzing the corpus, we found the following variations of modals with the verb $5 \mathrm{kar}$ ) 'do'. These modals have been observed to come often with the other verbs and showing the same semantic properties. The modal phrases take the subcategorization frame $\langle\mathrm{SUBJ}, \mathrm{OBJ}\rangle$ in all the phrases used because of the main verb كر. In phrases with other main verbs, 
the sub-categorization frames may differ. For example, in the sentence (XIV) as follows:

(XIV). احمد اسلم كو كتاب دن آيا

Ah2mad Aslam kO kitAb dE AyA

'Ahmed has given the book to Aslam [and returned]'

The modal verb بَ here does not determine the subcategorization frame. This is not an exception but a rule.

The modal verbs do follow agreement rules. They inflect in gender and number with either subject or object. In case of verbs that have <SUBJ, OBJ, OBJ1> sub-categorization frame, if the modal verb has to agree with direct object, it agrees with OBJ. For example in the sentence in (XV) as follows:
(XV). احمدنه اسلم كو كتاب دن دى

Ah2mad nE Aslam kO kitAb dE dI

'Ahmed has given the book to Aslam'

The sub-categorization frame becomes اسلح ,كتاب , احمد>, then the modal verb دى agrees with كتى in gender. The modal verbs also agree with the case of the noun phrases. Hence they determine the case of the verb phrase. The case required by the modals must be provided by the noun phrase structure. Table 1 lists the case requirement with all the modal verbs mentioned. These rules have been taken care of in the implementation of LFG. The screen shots of the run are depicted in the Appendix.

Table 1: Modal variations with the verb

\begin{tabular}{|c|c|c|c|}
\hline Semantic Properties & Agrees with & Case Required & Modal Verb types \\
\hline \multicolumn{4}{|c|}{ Modals for relationships } \\
\hline Interactive & OBJ & Ergative & كر ديا ker dia (did something) \\
\hline Personal & OBJ & Ergative & كر لبا ker lia (finish doing something) \\
\hline \multicolumn{4}{|c|}{ Modals for processes } \\
\hline Complete & SUBJ & Nominative & كر جكا ker chuka (did completely) \\
\hline Starting & SUBJ & Nominative & كرنـ لكأ kernay laga (begin to do) \\
\hline Lapsed & SUBJ & Nominative & كر بيثها ker baitah (did impulsively) \\
\hline Performed & OBJ & Ergative & kر كهابيا ker dikhaya (perfomed something) \\
\hline Successful & SUBJ & Nominative & كر كَيا ker gia (someone performed/did) \\
\hline \multicolumn{4}{|c|}{ Modals for ability } \\
\hline Able & SUBJ & Nominative & كر سكا ker saka (could do) \\
\hline Marginally Able & SUBJ & Nominative & كر بايا ker paya (could do) \\
\hline Spontaneous & SUBJ & Nominative & كر يزًا ker para (suddenly done/happened) \\
\hline Unavoidable & OBJ & Dative & كرنا يزخا kerna para (must/obliged to do) \\
\hline Binding & OBJ & Dative & kerna ho ga (will have/bound to do) \\
\hline Needed & OBJ & Dative & كرنا تها kerna tha (supposed/needed to do) \\
\hline Advised & not agree & Dative & kرنا جائب kerna chahiyeea (should do) \\
\hline \multicolumn{4}{|c|}{ Modals for mobility } \\
\hline Approaching & SUBJ & Nominative & kر آليا ker aya (arrival after doing) \\
\hline Leaving & SUBJ & Nominative & كر جلا ker chala (departure after doing) \\
\hline Leaving for Good & SUBJ & Nominative & كر عزرا ker guzra (left after doing) \\
\hline \multicolumn{4}{|c|}{ Modals for likelihood } \\
\hline Indifferent & SUBJ & Nominative & Kرئا بو كا karta ho ga (must doing/use to do) \\
\hline Suggestive & SUBJ & Nominative & كر سكنا بـ ker sakta hey (can do) \\
\hline
\end{tabular}

\section{DISCUSSION}

Section 2 shows six different modal verbs with variations in meaning and case required. We have expanded the types to 19 different ones classified into five major categories of relationships, processes, ability, mobility and likelihood.
In English the modals have the major categories of epistemic and deontic. Here epistemic maps to our category of likelihood and deontic maps to the category of ability. However, the finer changes in the meaning identified in the 19 types, have not been identified before. Hence, we see more information encoded in the modal verb structure of Urdu. 
During this work, it was seen that modals can behave as verb and auxiliary in Urdu like مين جابوب كا (mEN cAhUN gA) 'I will want'. Here جابو 'want' is behaving as modal verb with subjunctive morphological form. On the other hand, مي جانا جابتا تها (mEN jAnA cAhtA thA) 'I had wanted to go'. In this sentence جابتا 'want' is behaving as an aspectual modal auxiliary with imperfective morphology. This difference noted is quite interesting and plan to cover up in future work.

\section{CONCLUSION}

Except the future work mentioned in Section 4, Modal verb expressions that have been shown are divided into five major categories of relationships, processes, ability, mobility and likelihood, which are further broke down into 19 different types. Modals govern the sentence case and agree with either subject or object which is demonstrated in this paper. In future, this work of Urdu modals will be extended into further categories according to their behavior as a verb or as an auxiliary.

\section{REFERENCES}

[1] Agha, Asif. 1998, 'Form and Function in Urdu-Hindi verb inflection', The Yearbook of South Asian Languages and Linguistics, New Delhi, London. Sage Publications

[2] Bashir, Elena. 1999. 'The Urdu postposition ne: its changing role in the grammar', The Yearbook of South Asian Languages and Linguistics, New Delhi, London. Sage Publications

[3] Céline Roméro. 2005. The Syntactic Evolution of Modal Verbs in the History of English, Université Paris III - La Sorbonne Nouvelle, U.F.R. d’Anglais

[4] Englishpage.com - Free online English lessons \& ESL / EFL resources, Modal Verb Tutorial, available at http://www.englishpage.com/modals/modalintro.html

[5] George Cardona, Dhanesh Jain. 2003. The Indo Aryan Languages. Routledge language family series, UK.

[6] Hassan Sajid. 2007. Urdu Part of Speech Tagset, Center for Research in Urdu Language Processing, National University of Computer \& Emerging Sciences, Lahore Pakistan, available at www.crulp.org
[7] Ian Jacobs. 1995. English Modal Verbs, copyright @Ian Jacobs 1995-2000 http://www.w3.org/People/Jacobs/modals.ps.

[1] Ruth Laila Schmidt. 2004. Urdu: An Essential Grammar, Routledge, UK.

[2] Thomas Herbst. 1999. English Valency Structures-A First Sketch. Erfurt Electronic Studies in English (EESE Journal). Niedersächsische Staats- und Universitätsbibliothek Göttingen. ISSN 1430-6905.

[3] Abbas Q. and Raza G. 2014. A Computational Classification of Urdu Dynamic Copula Verb. International Journal of Computer Applications (IJCA), Vol. 85(10), P 1-12, ISSN 0975 - 8887. Published by Foundation of Computer Science, New York, USA.

[4] Abbas, Q. 2012. Building a Hierarchical Annotated Corpus of Urdu: The URDU.KON-TB Treebank. Lecture Notes in Computer Science (LNCS). Vol. 7181(1), P 6679, ISSN 0302-9743, Springer-Verlag Berlin/Heidelberg.

[5] Abbas, Q. Karamat, N. Niazi,S. 2009. Development of Tree-bank based probabilistic grammar for Urdu Language. International Journal of Electrical \& Computer Science (IJECS), Vol. 09(09), P 231-235, ISSN 2077-1231.

[6] Abbas Q. 2014. Exploiting Language Variants Via Grammar Parsing Having Morphologically Rich Information. In Proceedings of the EMNLP'2014 Workshop on Language Technology for Closely Related Languages and Language Variants, Association of Computational Linguistics, P 35-45, Qatar.

[7] Abbas Q. 2014. Semi-Semantic Part of Speech Annotation and Evaluation. In Proceedings of ACL 8th Linguistic Annotation Workshop (COLING), Association of Computational Linguistics, $\mathrm{P}$ 75-81, Ireland.

[8] Abbas, Q. Khan, N.A. 2009. Lexical functional grammar for Urdu modal verbs. In Proceedings of 5th IEEE International Conference on Engineering and Technology (ICET).

[9] Abbas, Q. 2014. Building Computational Resources: The URDU.KON-TB Treebank and the Urdu Parser, Doctoral Dissertation, University of Konstanz, Germany

\section{APPENDIX}

Sentences of Urdu are encoded in English alphabets. Only five and half out of nineteen screen shots of results mentioned in Table 1 are displayed in this paper to provide an idea about classification and their analysis through XLE parser. The C and $\mathrm{F}$ structure of a sentence in (XVI) is depicted in the following screen shots.

(XVI). سارهن كام كر ديا

Sara ne kam ker diya

'Sara has done (shows interactive modality) the work'

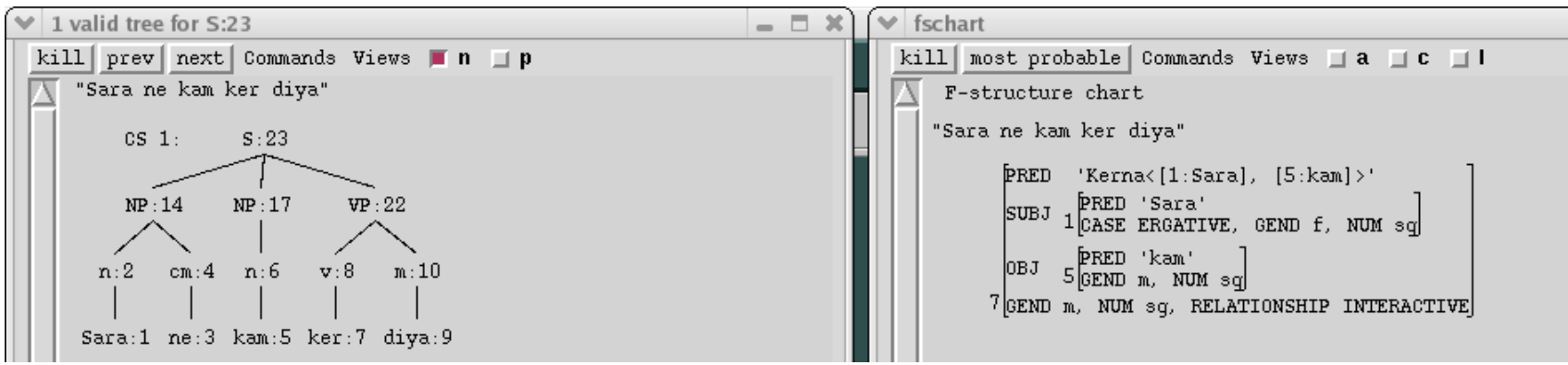




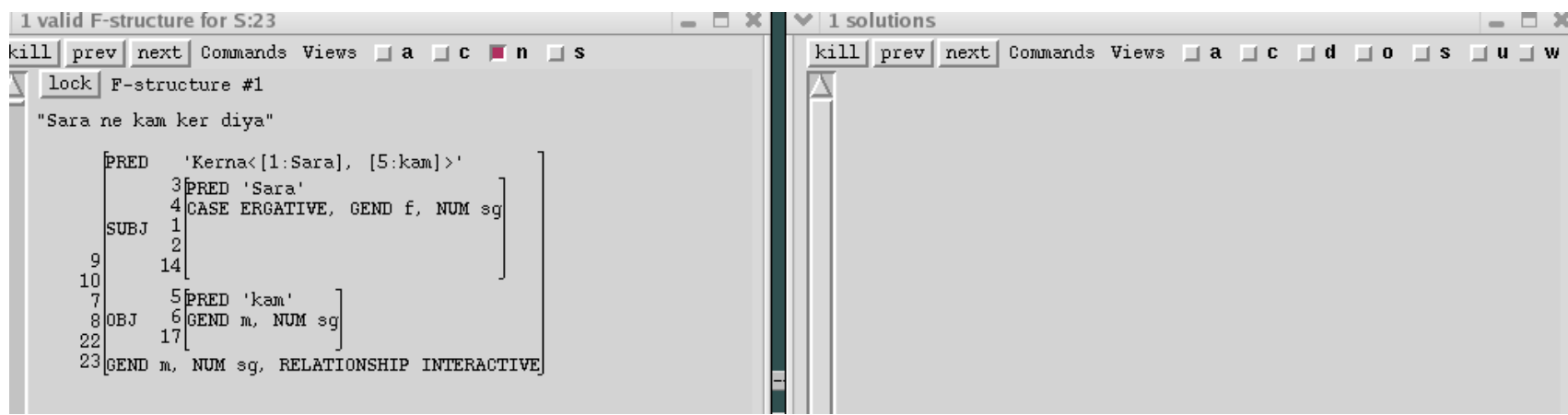

(XVII). سارن نـ كام كر ليا

Sara ne kam kar liya

'Sara has done (personal modality) the work'

The sentence given in (XVII) has the following $\mathrm{C}$ and $\mathrm{F}$ structure produced in the analysis during parsing, which shows the personal ability of 'Sara' to finish the work.

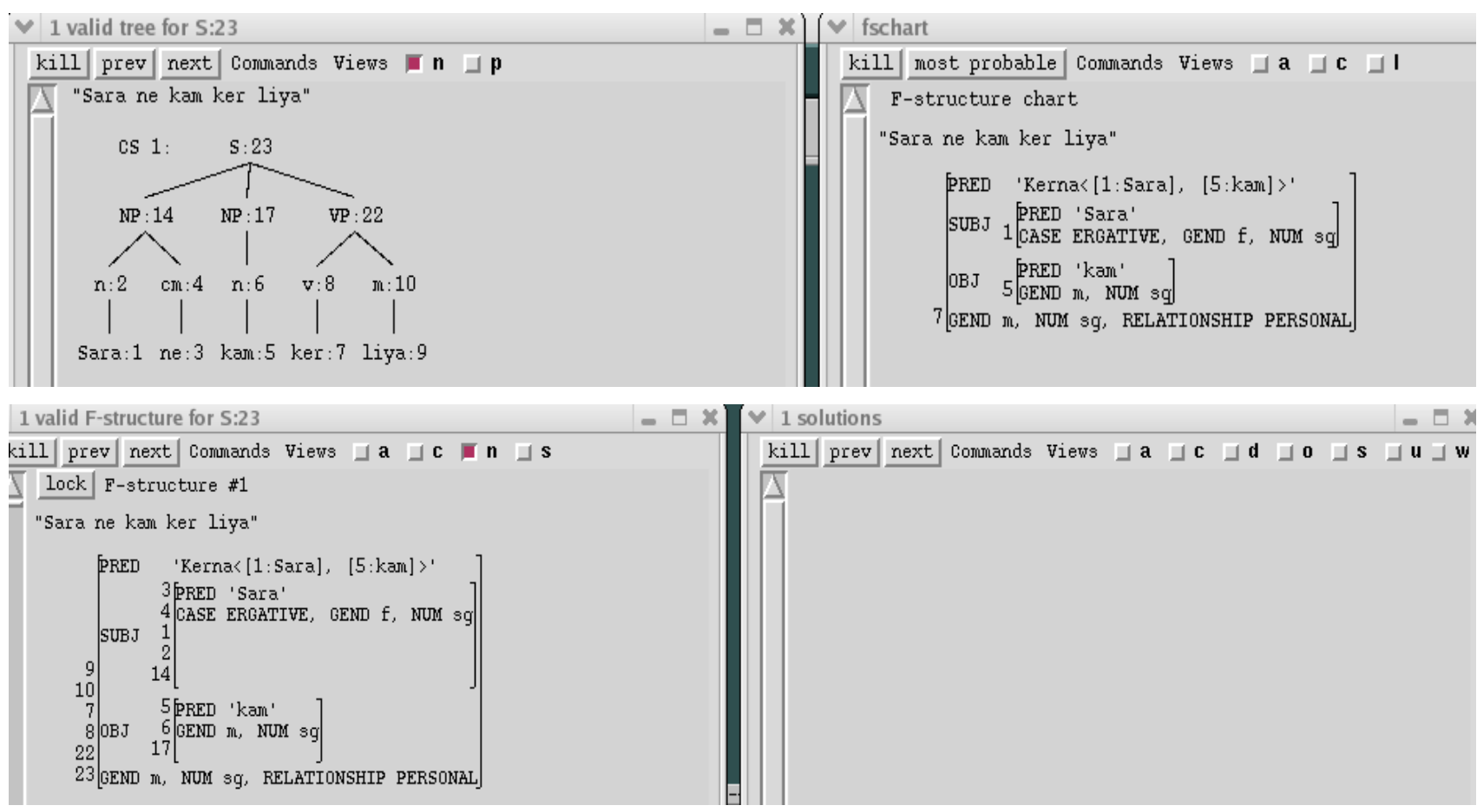

(XVIII). ساره كام كر جְكى

Sara kam ker chuki

'Sara has done (completion modality) the work'

The sentence given in (XVIII) shows the completion of work, hence concluding completion modality.

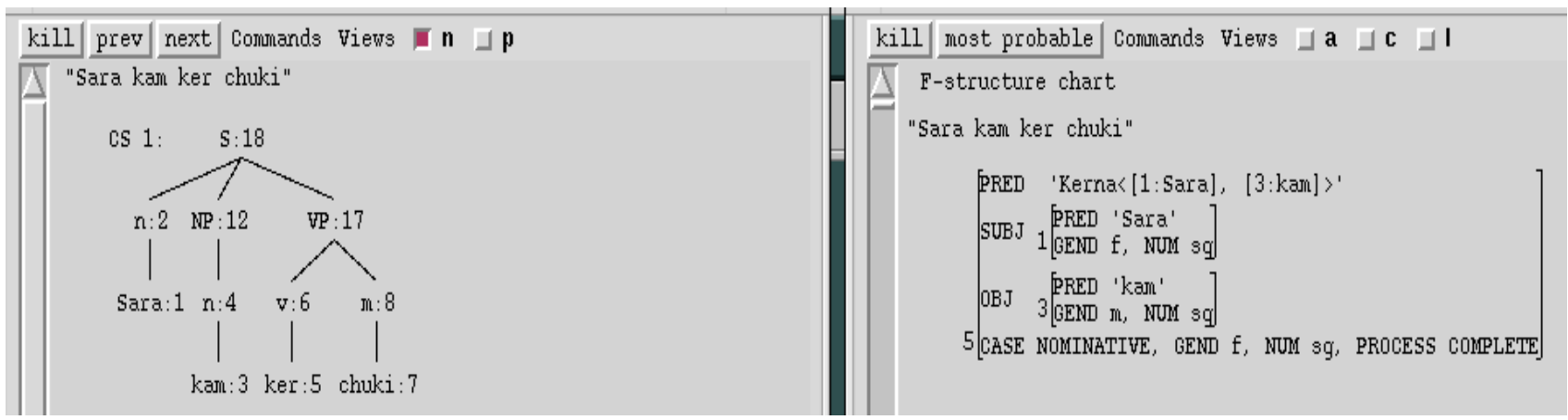




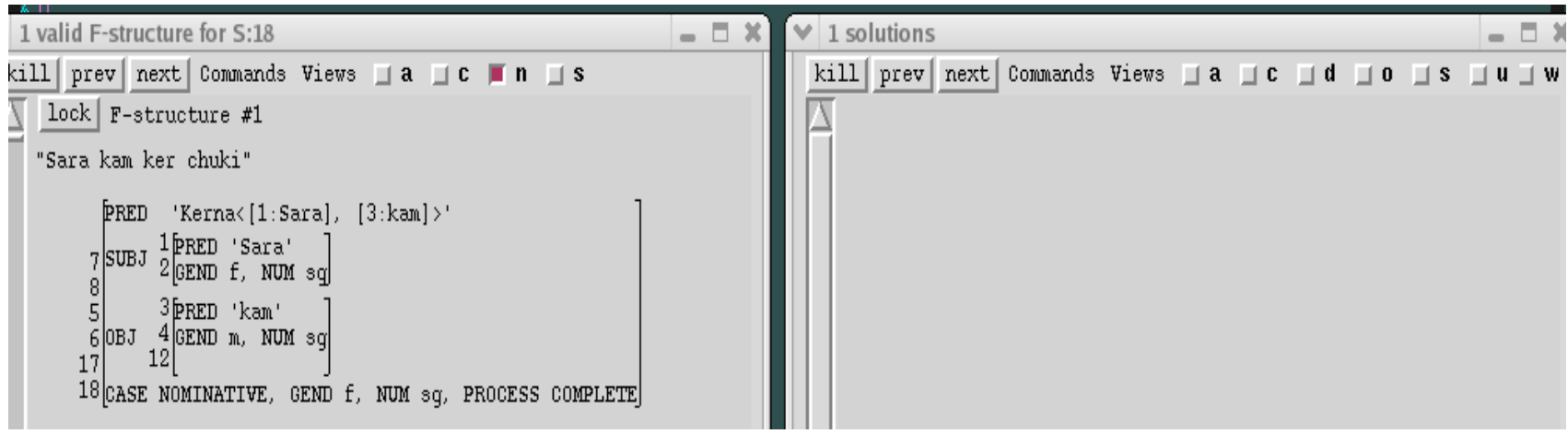

(XIX). ساره كام كرنه لغحى

Sara kam karnay lagi

'Sara is going to start (starting modality) the work'

The sentence in (XIX) shows the starting modality of an event by 'Sara', The screen shots are as follows.

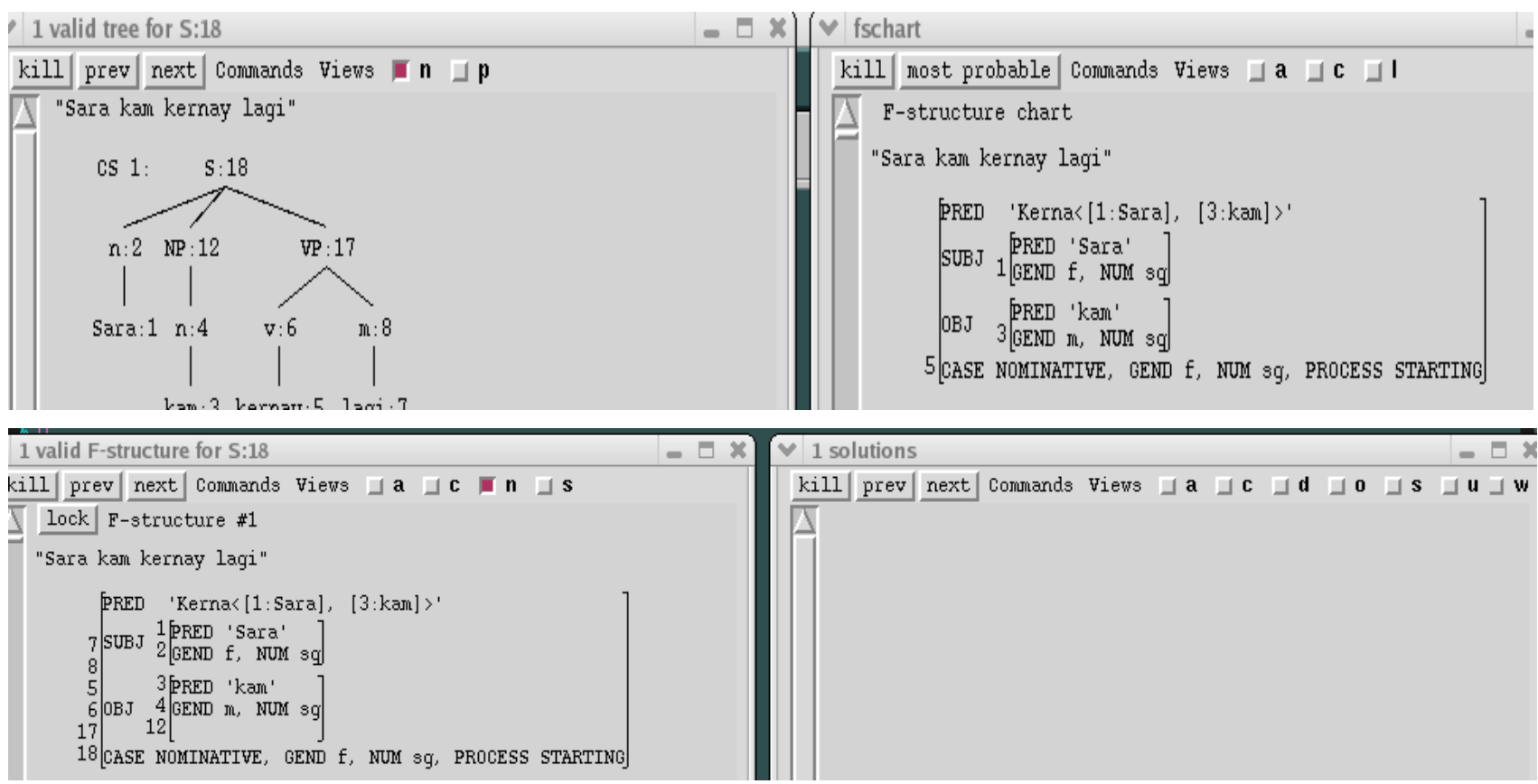

(XX). ساره كام كر بيئهى

Sara kam ker baithi

'Sara has finished (lapsed modality) the work'

The screen shots as follows depicts the analysis of lapsed modality resides in the sentence in (XX).

1 valid tree for S:18




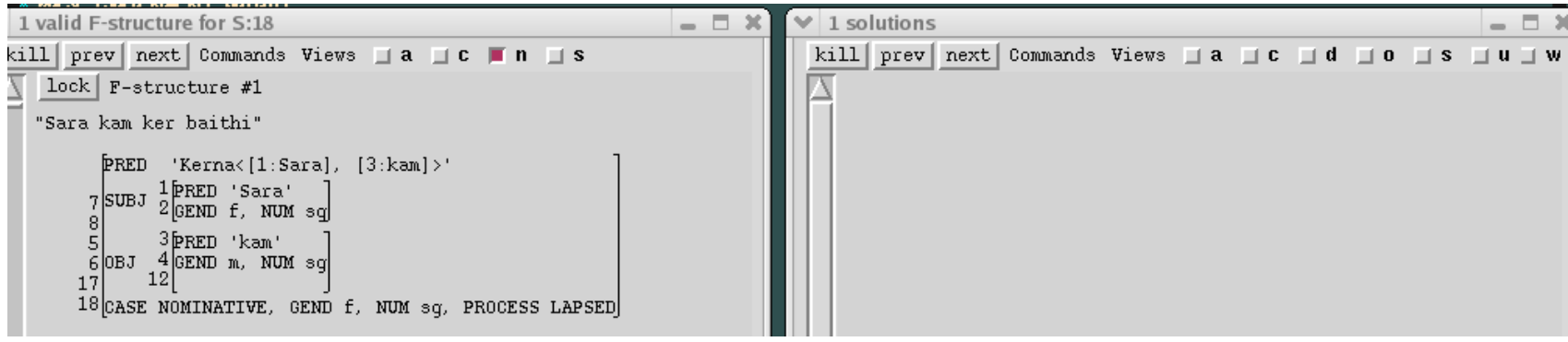

(XXI). سارهن كام كر دكهايا

Sara ne kam ker dikhaya

'Sara shows the ability of perform the work'

Similarly, the ability to perform analyzed through parsing the sentence (XXI) is depicted in the following screen shot.

1 valid tree for S:23

